\title{
Eksplorasi Bakteri Pendegradasi Minyak dari Perairan Pelabuhan Tanjung Mas, Semarang
}

\author{
Ita Puspitasari*, Agus Trianto, Jusup Suprijanto \\ Departemen IImu Kelautan, Fakultas Perikanan dan IImu Kelautan, Universitas Diponegoro \\ JI. Prof. H. Soedarto S.H, Tembalang, Semarang, Jawa Tengah 50275 Indonesia \\ *Corresponding author, e-mail : itapusspitasari@gmail.com
}

\begin{abstract}
ABSTRAK: Tanjung Mas merupakan salah satu kawasan pelabuhan di Jawa Tengah yang terus mengalami peningkatan jumlah kapal setiap tahunnya. Hal ini berimbas pada semakin meningkatnya tumpahan minyak solar yang masuk ke perairan. Upaya yang bisa dilakukan untuk mengurangi jumlah tumpahan minyak solar di Pelabuhan Tanjung Mas yaitu dengan melakukan penelitian bioremediasi menggunakan bakteri indigenouse. Tujuan penelitian ini dilakukan yaitu mendapatkan isolat bakteri air laut asal Pelabuhan Tanjung Mas, Semarang yang mampu mendegradasi minyak solar dan mengetahui kemampuan masing-masing isolat untuk mendegradasi minyak solar. Penelitian ini dilaksanakan pada bulan Juli sampai Oktober 2019 dengan pengambilan sample air laut menggunakan metode purpossive sampling, metode isolasi menggunakan pour plate, metode uji minyak secara gravimetri dan pertumbuhan bakteri menggunakan Standart Plate Count (SPC). Hasil isolasi yaitu didapatkan 2 isolat unggul yaitu bakteri Alcanivorax nanhaiticus dan Halomonas meridiana. Bakteri Alcanivorax nanhaiticus mampu mendegradasi $54 \%$ minyak solar dan Halomonas meridiana mampu mendegradasi $72 \%$ minyak solar. Kedua bakteri merupakan bakteri hidrokarbonoklastik atau bakteri yang memiliki kemampuan mendegradasi minyak solar (hidrokarbon) karena mengandung enzim monooksigenase. Dari penelitian ini dapat disimpulkan bahwa di Pelabuhan Tanjung Mas terdapat bakteri yang mampu mendegradasi minyak solar yaitu Alcanivorax nanhaiticus dan Halomonas meridiana. Kedua isolat mampu mendegradasi lebih dari 50\% minyak solar yang diujikan.
\end{abstract}

Kata kunci: isolasi; bakteri; biodegradasi; minyak solar; Pelabuhan Tanjung Mas

\section{Exploration of Oil Degradation Bacteria from Tanjung Mas Port Waters, Semarang}

ABSTRACT: Tanjung Mas is one of the port areas in Central Java that continues to experience an increase in the number of ships each year. This has an impact on the increasing amount of diesel fuel spills that enter the waters. Efforts that can be made to reduce the number of diesel fuel spills in the Port of Tanjung Mas is to conduct bioremediation research using indigenous bacteria. The purpose of this study was to obtain seawater bacterial isolates from the Port of Tanjung Mas, Semarang that can degrade diesel fuel and determine the ability of each isolate to degrade diesel fuel. This research was conducted in July to October 2019 by taking seawater samples using a purposive sampling method, isolation method using pour plates, gravimetric fuel test methods and bacterial growth using Standard Plate Count (SPC). The results of the isolation were obtained 2 superior isolates namely Alcanivorax nanhaiticus and Halomonas meridiana. Alcanivorax nanhaiticus can degrade $54 \%$ of diesel fuel and Halomonas meridiana can degrade $72 \%$ of diesel fuel. Both bacteria are hydrocarbonoclastic bacteria or bacteria that can degrade diesel oil (hydrocarbons) because they contain the enzyme monooxsigenase. From this study, it can be concluded that at Tanjung Mas Port there are bacteria that can degrade diesel fuel, namely Alcanivorax nanhaiticus and Halomonas meridiana. Both isolates were able to degrade more than $50 \%$ of the tested diesel fuel.

Keywords: isolation; bacteria; biodegradation; diesel fuel; Tanjung Mas Port

\section{PENDAHULUAN}

Secara alami, mikroba di alam ditemukan dalam populasi campuran. Metode yang bisa dilakukan untuk mendapatkan biakan murni disebut isolasi. Menurut Mikdarullah dan Nugraha 
(2017), prinsip dari isolasi mikroba adalah memisahkan atau memindahkan mikroba tertentu dari lingkungannya di alam dan menumbuhkannya di media buatan sehingga diperoleh kultur murni atau biakan murni. Menurut Cappuccino dan Sherman (2002), isolasi dapat dilakukan dengan cara sebar (spread-plate), tuang (pour-plate) atau gores (streak-plate). Isolasi dan seleksi awal akan menentukan bakteri mana yang sesungguhnya berperan dan berpotensi untuk dikembangkan dan dimanfaatkan secara khusus dalam penanganan pencemaran minyak atau lemak (Susanti et al., 2007).

Menurut Arisandi (2017), bakteri merupakan mikroorganisme bersel tunggal dengan ukuran panjang $0,5-10 \mu$ dan memiliki lebar $0,5-2,5 \mu$. Bakteri adalah suatu struktur sel yang tidak mempunyai inti sejati (inti yang tidak dikelilingi membran inti), sedangkan komponen genetiknya terdapat di dalam molekul DNA tunggal yang letaknya bebas di dalam sitoplasma (Ali, 2005). Bakteri yang mampu mendegradasi senyawa yang terdapat di dalam hidrokarbon minyak bumi disebut bakteri hidrokarbonoklastik (Lasari, 2010). Bakteri ini mampu mendegradasi senyawa hidrokarbon dengan memanfaatkan senyawa tersebut sebagai sumber karbon dan energi yang diperlukan bagi pertumbuhannya.

Minyak solar adalah senyawa hidrokarbon jenuh yang pada formulasi blending menggunakan biodiesel yang semakin banyak akan mengakibatkan bilangan iod dari biosolar yang dihasilkan semakin besar (Haryono dan Marliani, 2014). Bakteri hidrokarbonoklastik mampu mendegradasi minyak solar karena bantuan enzim monooksigenase dan enzim dioksigenase. Enzim monooksigenase dan enzim dioksigenase yang dihasilkan oleh bakteri mampu membuka ikatan karbon pada cincin aromatik dan menghasilkan alkohol primer (Hasyimuddin et al., 2016). Melalui pemberian satu molekul oksigen maka enzim monooksigenase juga dapat mendegradasi $\mathrm{PAH}$ dan membentuk arene oksida, selanjutnya molekul-molekul ini akan digunakan oleh mikroba sebagai sumber nutrisi untuk pertumbuhan dan energi.

Tanjung Mas merupakan salah satu pelabuhan strategis di Indonesia yang mengalami kenaikan arus kedatangan kapal setiap tahunnya (Aji et al., 2013). Aktivitas manusia di sekitar Pelabuhan Tanjung Mas menyebabkan jumlah pencemaran minyak di air laut Pelabuhan Tanjung Mas terus meningkat. Menurut Suyasa (2006), pada lingkungan yang telah tercemar serta kolam pengolahan limbah dimungkinkan terdapat bakteri pendegradasi minyak tersebut secara alamiah, bersaing, maupun berkonsorsia dengan mikroorganisme lainnya. Oleh karena itu, perlu dilakukannya penelitian ini dengan tujuan mendapatkan isolat bakteri pendegradasi minyak solar dan mengetahui kemampuan setiap isolat untuk mendegradasi minyak solar.

\section{MATERI DAN METODE}

Metode yang digunakan dalam penelitian yaitu metode deskriptif eksploratif. Metode ini bertujuan menggambarkan keadaan suatu fenomena. Data yang diperoleh dianalisis secara deskriptif yang dilaporkan dalam bentuk tabel dan grafik (Hasyimuddin et al., 2016).

Metode pengambilan sampel air laut yang digunakan adalah purposive sampling method di 3 stasiun yaitu stasiun 1 di dermaga dalam 2, stasiun 2 di dermaga dalam 1, dan stasiun 3 di sebelah barat Semarang Container Terminal dengan masing-masing stasiun 3x pengulangan. Selain dilakukan pengambilan sampel air laut, parameter fisika kimia yang meliputi salinitas, DO, suhu dan $\mathrm{pH}$ diukur.

Satu $\mathrm{mL}$ air laut diambil dan ditumbuhkan dalam media SMSSe cair steril. Media SMSSe berasal dari media SMSS yang ditambahkan ekstrak ragi. Media SMSS terdiri dari 5 gram $\mathrm{CaCO}_{3}$, 2,5 gram $\mathrm{NH}_{4} \mathrm{NO}_{3}, 1$ gram Na2HPO4.7H2O, 0,5 gram $\mathrm{KH}_{2} \mathrm{PO} 4,0,5$ gram MgSO $4.7 \mathrm{H}_{2} \mathrm{O}$, dan 0,2

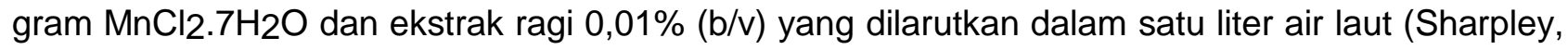
1966). Ekstrak ragi sebanyak 0,01\% (b/v) ditambahkan ke dalam medium SMSS sebagai sumber nitrogen tambahan. Medium tersebut ditambahkan minyak solar sebanyak $2 \%(\mathrm{v} / \mathrm{v})$ sebagai sumber karbon. Sampel dihomogenkan dengan shaker selama 3 hari dengan kecepatan $120 \mathrm{rpm}$ (rotasi per menit). Sampel diambil $1 \mathrm{~mL}$ dan diencerkan sampai $10^{-5}$ dengan menggunakan $\mathrm{NaCl}$ fisiologis steril. Hasil pengenceran $10^{-3}$ sampai dengan $10^{-5}$ dibiakkan dalam media SMSSe padat dengan metode pour plate. Hasil pour plate diinkubasi selama $2 \times 24$ jam pada suhu $37^{\circ} \mathrm{C}$ (Hasyimuddin et al., 2016).

Lima isolat bakteri yang berbeda dipurifikasi kemudian ditanam ke dalam media SMSSe 
padat dengan 3 konsentrasi minyak solar yaitu 2\%, 5\% dan 10\%. Inokulasi bakteri menggunakan metode streak. Cawan petri yang telah berisi bakteri kemudian diinkubasi pada suhu $37^{\circ} \mathrm{C}$ selama 2x24 jam. Isolat yang berhasil tumbuh pada 3 konsentrasi kemudian diamati secara morfologi. Pengamatan morfologi koloni dilakukan untuk melihat bentuk, elevasi, ukuran, tepi, dan warna koloni. Selain menggunakan pengamatan morfologis, uji molekuler juga dilakukan untuk mengetahui spesies bakteri.

Isolat yang berhasil diisolasi diuji secara gravimetri dan dihitung pertumbuhan bakteri. Masingmasing isolat bakteri yang telah dimurnikan sejumlah $10^{-5} \mathrm{sel} / \mathrm{ml}$ diambil lalu ditambahkan ke dalam tabung reaksi berisi media SMSSe cair dan minyak solar sebanyak $2 \%(\mathrm{v} / \mathrm{v}), 5 \%(\mathrm{v} / \mathrm{v})$, dan 10\% (v/v) secara terpisah. Kultur dihomogenkan dengan shaker pada kecepatan 120 rpm (rotasi per menit). Analisis kadar minyak solar tersisa dan estimasi kepadatan bakteri dihitung pada hari ke 7 dan 14 . Perlakuan yang sama juga dilakukan pada kontrol namun perlakuan ini tidak menggunakan isolat bakteri (Hasyimuddin et al., 2016).

Analisis kadar minyak solar secara gravimetri dapat dilakukan dengan cara media SMSSe cair yang mengandung solar $2 \%(\mathrm{v} / \mathrm{v})$ hasil perlakuan dimasukkan ke dalam corong pemisah. $\mathrm{N}$-heksana dicampur dengan media SMSSe cair kemudian dihomogenkan selama \pm 15 menit lalu didiamkan sampai n-heksana terpisah. Terdapat 3 lapisan yaitu minyak solar, n-heksana, dan air. Air dibuang, lapisan minyak solar dan n-heksana disaring dengan kertas saring. Proses destilasi dimulai dengan memanaskan labu alas bulat pada suhu $60^{\circ} \mathrm{C}$ (sesuai dengan titik didih n-heksana) sampai $\mathrm{n}$ - heksana habis dan yang tersisa hanya minyak. Gelas kimia tersebut diangkat dan didiamkan sampai dingin lalu ditimbang dan dicatat beratnya. Menurut Bhaktinagara et al. (2015), kadar minyak solar dihitung dengan cara sebagai berikut : \%TPH= Berat residu: berat sampel $\mathrm{x}$ $100 \%$

Metode lain yang digunakan untuk mengetahui kadar minyak tersisa hasil degradasi adalah menggunakan buret. Media yang berisi minyak solar dan isolat bakteri dimasukkan ke dalam buret kemudian diukur berdasar skala yang ada. Hasil yang didapat merupakan hasil pengukuran kotor. Kepadatan sel isolat bakteri masing-masing perlakuan dihitung dengan cara Standard Plate Count (SPC) dengan menggunakan colony counter pada hari ke 7 dan 14. Metode cawan tuang (pour plate) digunakan untuk inokulasi bakteri. Sampel yang ada di media SMSSe cair dengan konsentrasi minyak solar $2 \%, 5 \%$ dan $10 \%$ diambil $1 \mathrm{~mL}$ dan dilakukan pengenceran kembali sampai $10^{-5}$ menggunakan $\mathrm{NaCl}$ steril. Selanjutnya dilakukan pour plate. Menurut Bhaktinagara et al. (2015), kultur diinkubasi selama 2 hari pada suhu $32^{\circ} \mathrm{C}$ dan dihitung kepadatan sel bakterinya dengan cara: $\mathrm{CFU} / \mathrm{mL}=$ Jumlah koloni per cawan $\mathrm{x}$ faktor pengenceran :volume inokulasi $(\mathrm{mL})$. Faktor pengenceran $=1$ :tingkat pengenceran

Uji molekuler digunakan untuk analisis mikroorganisme dari makanan atau material biologis lainnya (Babalola, 2003). Umumnya, uji molekuler digunakan untuk mengetahui spesies atau jenis dari DNA atau protein. Ada 4 tahapan dari uji molekuler yaitu ekstraksi DNA, amplifikasi dan visualisasi DNA, sekuensing DNA, dan analisis filogenetik.

Ekstraksi DNA merupakan tahapan awal dari uji molekuler. Sampel yang telah diinkubasi selama 1x24 jam diambil sebanyak 1 goresan penuh kemudian diletakkan dalam microtube steril.

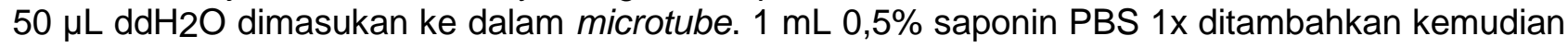
diletakkan ke dalam freezer selama 1x24 jam. Sampel kemudian dihomogenkan dengan vortex berkecepatan 12.000 RPM (Rotasi Per Menit) selama 10 menit. Natan dan supernatan dipisahkan. $100 \mu \mathrm{L}$ ddH2O dan $50 \mu \mathrm{L} 20 \%$ Chelex 100 dimasukan ke dalam microtube dan dihomogenisasi secara merata. Microtube dipanaskan hingga mendidih selama kurang lebih 10 menit dan dihomogenkan dengan vortex setiap 5 menit sekali dengan kecepatan 12000 RPM (Rotasi Per Menit). Supernatan yang didapatkan kemudian dipindahkan ke dalam microtube baru. Suspensi sel dibekukan pada suhu $-20^{\circ} \mathrm{C}$ dan dicairkan pada suhu $90^{\circ} \mathrm{C}$ selama 10 menit (Nursyirwani dan Amolle, 2007).

Proses elektroforesis dimulai dengan mencampurkan $45 \mathrm{~mL}$ aquadest dan 0,45 gram agarose 1\% (Nursyirwani dan Amolle, 2007). Gel dimasukkan ke dalam cetakan dalam keadaan hangat. Setelah dicetak, gel dimasukkan dalam wadah elektroforesis dan ditambahkan buffer. $\mathrm{DdH} 2 \mathrm{O}$ dimasukkan pada lubang pertama dilanjutkan dengan sampel hasil ekstraksi. Proses elektroforesis dimulai selama kurang lebih 3 jam. Gel hasil elektroforesis dimasukkan ke dalam Biobase Gel System dan terlihat hasil band nya. 
Amplifikasi DNA dilakukan dengan PCR bersekuen 16S rDNA menggunakan mesin Thermal Cycler. Untuk proses PCR $16 \mathrm{~S}$ bervolume $10 \mu \mathrm{L}$, aquabidest $2 \mu \mathrm{L}$, Primer $27 \mathrm{~F} 1 \mu \mathrm{L}$, Primer $1492 \mathrm{R} 1$ $\mu \mathrm{L}$, DNA template $1 \mu \mathrm{L}$ dan Megamix Royal $5 \mu \mathrm{L}$ dimasukkan ke dalam tabung eppendorf (Nursyirwani dan Amolle, 2007). Mesin Thermal Cycler dijalankan dan diprogram berdasarkan suhu: proses denaturasi pada suhu $90^{\circ} \mathrm{C}$ selama 2 menit, proses annealing dengan suhu $50^{\circ} \mathrm{C}$ selama 40 detik, suhu $72^{\circ} \mathrm{C}$ selama 1 menit dan suhu $94^{\circ} \mathrm{C}$ selama 40 detik. Pada proses ekstensi suhu diturunkan suhu $42^{\circ} \mathrm{C}$ selama 1 menit dan pada suhu $72^{\circ} \mathrm{C}$ selama 5 menit. Ketiga proses ini dijalankan sebanyak 30 siklus selama satu jam.

Proses sekuensing dilakukan dengan mencampurkan bahan-bahan Aquabidest $3 \mu \mathrm{L}$, Primer $2 \mu \mathrm{L}$, BigDye V3.1 $4 \mu \mathrm{L}$, dan Template $1 \mu \mathrm{L}$. Total volume menjadi $10 \mu \mathrm{L}$. Semua bahan dicampur dengan menggunakan pipet. Program PCR $16 \mathrm{~S}$ universal dijalankan dengan perlakuan suhu $96^{\circ} \mathrm{C}$ selama 2 menit, suhu $96^{\circ} \mathrm{C}$ selama 10 detik, suhu $55^{\circ} \mathrm{C}$ selama 5 detik dan suhu $60^{\circ} \mathrm{C}$ selama 4 menit (Nursyirwani dan Amolle, 2007).

Pohon filogenetik dilakukan dengan membandingkan sekuen DNA isolat bakteri hidrokarbonoklastik dibandingkan dengan sekuen DNA pada basis data (database) DNA. Penelusuran dilakukan dengan menggunakan internet melalui program pelacakan database Basic Local Alignment Search Tool (BLAST). Pembuatan pohon filogenetik menggunakan software Mega A6 dan data sekunder dari Basic Local Alignment Tool (BLAST) pada situs NCBI. Pada pembuatan pohon filogenetik, pilihan opsi model Tamamura-Nei dipilih dan metode neighbor joining tree digunakan. Tamamura-Nei method adalah model yang paling umum dipilih untuk membuat pohon filogenetik. Pada pembuatan pohon filogenetik ini diuji secara statistik menggunakan metode bootstrap replications sebanyak 1000 kali pengulangan.

\section{HASIL DAN PEMBAHASAN}

Keberadaan stasiun 1 yaitu pada koordinat $06^{\circ} 56^{\prime} 59,92^{\prime \prime} S 110^{\circ} 25^{\prime} 08,19^{\prime \prime}$ E. Stasiun 1 berlokasi di dekat dermaga pelabuhan dalam 2 dan alur pelayaran dari dan menuju kolam pelabuhan. Di Pelabuhan Tanjung Mas, stasiun 1 digunakan sebagai tempat bongkar muat kayu dan 9 bahan pokok. Kolam pelabuhan ini adalah tempat kapal berlabuh, berolah gerak, melakukan aktivitas bongkar muat, dan mengisi perbekalan. Stasiun 2 berada pada koordinat $06^{\circ} 56^{\prime} 50,88^{\prime \prime} S$ $110^{\circ} 25^{\prime} 15,85^{\prime \prime} \mathrm{E}$. Lokasi stasiun 2 yaitu di antara dermaga dalam 1 dan dermaga nusantara. Menurut Peraturan Menteri Perhubungan nomor 18 tahun 2013, dermaga nusantara digunakan untuk kegiatan kapal-kapal penumpang dan turis, untuk kegiatan kapal-kapal cargo/ curah, dan kegiatan kapal-kapal curah cair atau GC. Stasiun 3 berada pada titik koordinat 0656'27,86" S 110²5'16,30" E. Lokasi sampling ini berada di sebelah barat Semarang Container Terminal. Kegiatan yang umum dilakukan di Semarang Container Terminal adalah bongkar muat barang.
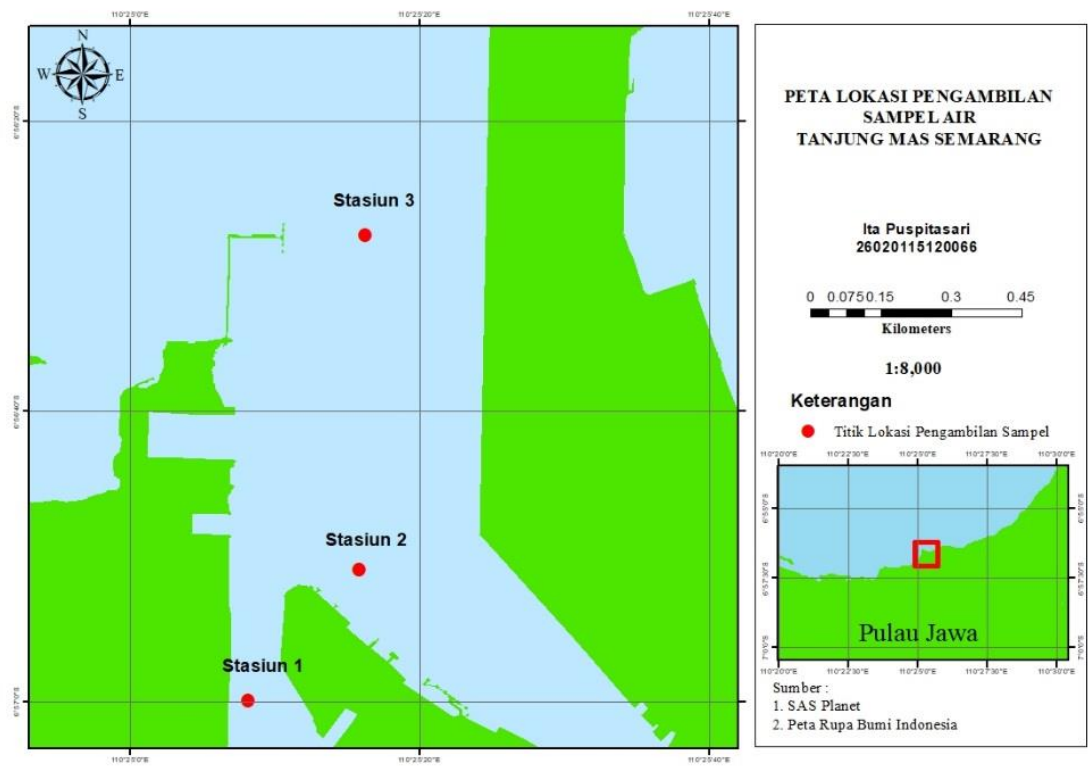

Gambar 1. Lokasi Pengambilan Sampel Air Laut 
Sampel air diambil di permukaan laut pada kedalaman 0-15 cm. Pada kedalaman ini jumlah bakteri sangat banyak karena nutrisi dan oksigen yang melimpah. Minyak solar umumnya digunakan sebagai sumber karbon untuk bakteri hidrokarbonoklastik. Selain mengambil sampel air laut dilakukan pengukuran parameter fisika kimia yang meliputi suhu, salinitas, $\mathrm{pH}$ dan DO. Suhu di stasiun 1,2 dan 3 sama yaitu $30 \pm 0,58^{\circ} \mathrm{C}$. Suhu ini merupakan suhu normal perairan. Pada suhu tersebut bakteri yang tumbuh dengan baik adalah bakteri mesofilik. Salinitas yang ada di stasiun 1 , 2 dan 3 sama yaitu 30 ppt. Pada salinitas ini, bakteri yang umum tumbuh adalah bakteri halofilik ringan. Menurut Arisandi et al. (2017), bakteri halofilik ringan berada pada pertumbuhan optimum yang bervariasi antara 20-50 ppt.

Tingkat keasaman $(\mathrm{pH})$ di lokasi sampling berkisar 7,99-8,09. Angka ini menunjukkan bahwa lokasi sampling dalam keadaan basa. $\mathrm{PH}$ optimum untuk proses biodegradasi hidrokarbon antara 6,0-8,0. Hal ini menunjukkan bahwa perairan Pelabuhan Tanjung Mas mampu mendegradasi hidrokarbon. Oksigen terlarut (DO) dibutuhkan oleh semua jasad hidup untuk pernapasan, proses metabolisme atau pertukaran zat yang kemudian menghasilkan energi untuk pertumbuhan dan pembiakan (Salmin, 2005). Di lokasi sampling, oksigen terlarut berkisar antara 5,83 sampai 6,83.

Ada 5 isolat yang diisolasi dari sampel air laut Pelabuhan Tanjung Mas. Kelima isolat diseleksi menggunakan media SMSSe padat dengan 3 konsentrasi minyak solar yaitu $2 \%, 5 \%$ dan $10 \%$. Hasil seleksi didapatkan 2 isolat unggul yang dapat tumbuh pada ketiga konsentrasi minyak solar. Isolat- isolat unggul diamati secara mikroskopik, makroskopik dan uji molekuler. Hasil pengamatan kedua isolat divisualisasikan dalam Tabel 1.

ISL 1A dan ISL 2A diuji kemampuan dalam mendegradasi minyak solar pada konsentrasi $2 \%, 5 \%$ dan $10 \%$. Hasil minyak solar terdegradasi di ketiga konsentrasi pada hari ke 7 dan ke 14 disajikan dalam Tabel 2.

Perbedaan nyata jumlah minyak solar tersisa di media yang berisi bakteri dengan media tanpa penambahan isolat bakteri (kontrol) menunjukkan bahwa bakteri ISL $1 \mathrm{~A}$ dan ISL 2A dapat memanfaatkan minyak sebagai sumber karbon dan mensintesis enzim-enzim yang digunakan dalam mendegradasi senyawa-senyawa yang terkandung di dalamnya. Proses pendegradasian terus mengalami peningkatan sampai dengan hari ke 14. Kadar minyak terdegradasi pada ISL $1 \mathrm{~A}$ dan ISL 2 A bersifat fluktuatif. ISL 1 A mampu mendegradasi $54 \%$ minyak solar sedangkan ISL 2 A mampu mendegradasi $72 \%$ minyak solar.

Kemampuan bakteri mendegradasikan minyak solar disebabkan karena bakteri menghasilkan enzim yang mampu memecah senyawa organik kompleks menjadi senyawa yang lebih sederhana (Hasyimuddin et al., 2013). Produksi enzim yang tinggi berhubungan dengan semakin tinggi kemampuan bakteri hidrokarbonoklastik dalam menguraikan senyawa hidrokarbon. Enzim yang dimiliki oleh bakteri pendegradasi minyak adalah oksigenase. Menurut Harayama et al. (1999), enzim tersebut berperan dalam reaksi masuknya oksigen ke dalam senyawa kimia melalui proses oksidasi. Enzim oksigenase dibagi menjadi 2 yaitu monooksigenase dan dioksigenase. Menurut Hasyimuddin et al. (2013), enzim monooksigenase dan enzim dioksigenase yang dihasilkan oleh bakteri mampu membuka ikatan karbon pada cincin aromatik dan menghasilkan alkohol primer. Enzim dioksigenase yang dihasilkan oleh bakteri mendegradasi PAH dan membentuk cis- dihidrodiol. Molekul-molekul yang ada selanjutnya akan digunakan oleh mikroba sebagai sumber nutrisi untuk pertumbuhan dan energi.

Pertumbuhan bakteri ISL 1A dan ISL 2A diamati selama 14 hari. Hasil pertumbuhan isolat bakteri disajikan dalam Tabel 3. Konsentrasi bakteri pada hari ke 7 dan ke 14 cenderung fluktuatif. Bakteri ISL 1A dan ISL 2A mampu tumbuh pada 3 konsentrasi minyak solar. Kemampuan degradasi suatu jenis mikroba terbatas hanya pada kisaran senyawa hidrokarbon tertentu, namun beberapa jenis mikroba akan bekerja secara bersamaan dalam mendegradasi minyak bumi sesuai spesifisitas substrat yang dimiliki (Harayama et al., 1999).

Jumlah bakteri paling banyak pada hari ke 7 dan kemudian mengalami penurunan pada hari ke 14. Hal ini disebabkan karena jumlah nutrisi di dalam media menjadi lebih sedikit. Menurut Umroh (2011), penurunan sel bakteri disebabkan oleh faktor kematian yang diduga karena berkurangnya kandungan nutrien $\mathrm{N}$ dan $\mathrm{P}$ di dalam sampel. Nitrogen merupakan unsur pokok protein yang berperan dalam pertumbuhan, perbanyakan sel dan pembentukan dinding sel. Phospor merupakan komponen utama asam nukleat dan lemak sel membran yang berperan dalam proses pemindahan energi secara biologi dan pembentukan asam amino. 
Tabel 1. Karakterisasi Isolat Bakteri Pendegradasi Minyak Solar

\begin{tabular}{|c|c|c|c|c|c|c|}
\hline \multirow{2}{*}{\multicolumn{2}{|c|}{ Pengamatan }} & \multirow{2}{*}{ Karakteristik } & \multicolumn{4}{|c|}{ Kode Isolat } \\
\hline & & & \multicolumn{2}{|c|}{ ISL $1 \mathrm{~A}$} & \multicolumn{2}{|c|}{ ISL 2A } \\
\hline \multirow{2}{*}{\multicolumn{2}{|c|}{ Makroskopik }} & Ukuran Koloni & Punctiform & & Small & \\
\hline & & $\begin{array}{l}\text { Bentuk Koloni } \\
\text { Tepi Koloni } \\
\text { Warna Koloni } \\
\text { Elevasi Koloni }\end{array}$ & $\begin{array}{l}\text { Circular } \\
\text { Entire } \\
\text { Putih } \\
\text { Convex }\end{array}$ & & $\begin{array}{l}\text { Circular } \\
\text { Entire } \\
\text { Kuning } \\
\text { Flat }\end{array}$ & \\
\hline \multicolumn{2}{|c|}{ Mikroskopik } & Pewarnaan Gram & Negatif & & Negatif & \\
\hline \multicolumn{2}{|c|}{ Uji Molekuler } & Bentuk Sel & $\begin{array}{l}\text { Batang } \\
\text { Alcanivorax }\end{array}$ & nhaiticus & $\begin{array}{l}\text { Batang } \\
\text { Halomona }\end{array}$ & ana \\
\hline \multicolumn{7}{|c|}{$\begin{array}{l}\text { Keterangan: }{ }^{*} \text { Punctiform (titik), }{ }^{*} \text { Small (kecil), }{ }^{*} \text { Circular (bulat bertepi), }{ }^{*} \text { Entire (rata/utuh), }{ }^{*} \text { Convex (timbul } \\
\text { melengkung), }{ }^{*} \text { Flat (datar) }\end{array}$} \\
\hline \multirow{2}{*}{$\begin{array}{l}\text { Kode } \\
\text { Isolat }\end{array}$} & \multicolumn{3}{|c|}{ Kadar Minyak Terdegradasi Hari ke 7 (\%) } & \multicolumn{3}{|c|}{$\begin{array}{c}\text { Kadar Minyak Terdegradasi Hari ke } 14 \\
(\%)\end{array}$} \\
\hline & & $5 \%$ & $10 \%$ & $2 \%$ & $5 \%$ & $10 \%$ \\
\hline Kontrol & & 0 & 0 & 0 & 0 & 0 \\
\hline ISL $1 \mathrm{~A}$ & & 36 & 10 & 40 & 54 & 44 \\
\hline ISL 2A & & 42 & 47 & 55 & 44 & 72 \\
\hline
\end{tabular}

Tabel 3. Konsentrasi Bakteri pada Berbagai Konsentrasi Minyak Solar Hari ke 7 dan ke 14

\begin{tabular}{ccccccc}
\hline Kode & \multicolumn{3}{c}{ Konsentrasi Bakteri pada Hari ke 7} & \multicolumn{3}{c}{ Konsentrasi Bakteri pada Hari ke 14 } \\
\cline { 2 - 6 } Isolat & $2 \%$ & $5 \%$ & $10 \%$ & $2 \%$ & $5 \%$ & $10 \%$ \\
\hline Kontrol & 0 & 0 & 0 & 0 & 0 & 0 \\
ISL 1A & $3.10^{5}$ & $1,1.10^{5}$ & $3,5.10^{5}$ & $0,3 \cdot 10^{5}$ & $0,3.10^{5}$ & $0,9.10^{5}$ \\
ISL 2A & $5,8.10^{5}$ & $0,8.10^{5}$ & $0,3.10^{5}$ & $0,6.10^{5}$ & $0,5 \cdot 10^{5}$ & $3.10^{5}$ \\
\hline
\end{tabular}

Jumlah sel bakteri Alcanivorax nanhaiticus dan Halomonas meridiana mengalami peningkatan seiring bertambahnya konsentrasi minyak solar. Hal ini disebabkan karena karbon merupakan sumber nutrisi untuk pertumbuhan. Menurut Hasyimuddin et al. (2016), bakteri dapat mendegradasi minyak solar karena bakteri menghasilkan enzim yang mampu memecah senyawa organik kompleks menjadi senyawa yang lebih sederhana. Bakteri yang memiliki pertumbuhan tertinggi juga akan menghasilkan kadar minyak yang terdegradasi tinggi. Hal ini menunjukkan telah dimanfaatkannya minyak sebagai sumber karbon untuk menghasilkan energi dan pertumbuhan bakteri (Umroh, 2011).

\section{KESIMPULAN}

Bakteri unggul yang berhasil diisolasi dari air laut Pelabuhan Tanjung Mas yaitu Alcanivorax nanhaiticus dan Halomonas meridiana. Kedua isolat merupakan bakteri yang dapat mendegradasi minyak solar pada konsentrasi $2 \%, 5 \%$ dan $10 \%$ dalam waktu 14 hari pengamatan. Alcanivorax nanhaiticus mampu mendegradasi $54 \%$ minyak solar sedangkan Halomonas meridiana mampu mendegradasi $72 \%$ minyak solar. 


\section{UCAPAN TERIMAKASIH}

Artikel ini merupakan bagian dari skripsi yang berjudul "Isolasi dan Seleksi Bakteri Pendegradasi Minyak Solar dari Perairan Pelabuhan Tanjung Mas, Semarang" untuk memperoleh gelar Sarjana Strata Satu Program Studi IImu Kelautan, Fakultas Perikanan dan Ilmu Kelautan, Universitas Diponegoro.

\section{DAFTAR PUSTAKA}

Aji, A.P., Paramarta., B., Edhisono, S. \& Kurniani, D. 2013. Perencanaan Pengembangan Pelabuhan Tanjung Emas, Semarang. Jurnal Karya Teknik Sipil, 2(4):218-227.

Ali, A. 2005. Mikrobiologi Dasar. Universitas Negeri Makassar Press. Makassar.

Arisandi, A., Tamam, B. \& Yuliandari, R. 2017. Jumlah Koloni pada Media Kultur Bakteri yang Berasal dari Tallus dan Perairan Sentra Budidaya Kappaphycus alvarezii di Sumenep. Jurnal IImiah Perikanan dan Kelautan, 9 (1):43-49. DOI: 10.20473/jipk.v9i1.7633.

Babalola, O.O. 2003. Molecular Techniques: An Overview of Methods for The Detection of Bacteria. African Journal of Biotechnology, 2 (12):710-713. DOI: 10.5897/AJB2003.000-1127.

Badan Pusat Statistik Provinsi Jawa Tengah. 2018. Jumlah Perahu/Kapal Menurut Kabupaten/Kota dan Jenis Kapal di Provinsi Jawa Tengah 2015.

Bhaktinagara, R.A., Suprihadi, A. \& Raharjo, B. 2015. Biodegradasi Senyawa Hidrokarbon oleh Strain Bacillus cereus (VIC) pada Kondisi Salinitas yang Berbeda. Jurnal Biologi., 4(3):62-71.

Buskey, E.J., White, H.K. \& Esbaugh, A.J. 2016. Impacts of Oil Spills on Marine Life in the Gulf of Mexico: Effects on Plankton, Nekton, and Deep-Sea Benthos. Oceanography, 29(3):174-181. DOI: 10.5670/oceanog.2016.81.

Cappuccino, J.G. \& N. Sherman. 2002. Microbiology: A Laboratory Manual, Sixth Edition. California: Benjamin/Cummings Science Publishing. $477 \mathrm{hlm}$.

Harayama, S., Kishira, H., Kasai, Y. \& Shutsubo, K. 1999. Petroleum Biodegradation in Marine Environments. Journal of Molecular Microbiology and Biotechnology, 1(1):63-70.

Haryono \& Marliani. 2014. Analisis Mutu Biosolar pada Variasi Formulasi Blending Biodiesel dari Minyak Biji Kapuk dengan Minyak Solar. Eksergi., 11 (2): 24. DOI: 10.31315/e.v11i2.343.

Hasyimuddin, Djide, M.N. \& Samawi, M.F. 2016. Isolasi Bakteri Pendegradasi Minyak Solar dari Perairan Teluk Pare-Pare. Biogenesis: Jurnal Ilmiah Biologi, 4(1):41-46. DOI: 10.24252/ bio.v4i1.1119.

Lasari, D.P. 2010. Bakteri Pengolah Limbah Minyak Bumi yang Ramah Lingkungan. Kementrian Energi dan Sumber Daya Mineral. www.esdm.go.id. 09 Juni 2020.

Mikdarullah \& Nugraha, A. 2017. Teknik Isolasi Bakteri Proteolitik dari Sumber Air Panas Ciwidey, Bandung. Buletin Teknik Litkayasa Akualkultur, 15(1):11-14. DOI: 10.15578/blta.15.1.2017. 11-14.

Nasikhin, R. \& Shovitri, M. 2013. Isolasi dan Karakterisasi Bakteri Pendegradasi Solar dan Bensin dari Perairan Pelabuhan Gresik. Jurnal Sains dan Seni Pomits, 2(2):2337-3520. DOI: 10.12962/j23373520.v2i2.3626.

Nugroho, A. 2007. Dinamika Populasi Konsorsium Bakteri Hidrokarbonoklastik: Studi Kasus Biodegradasi Hidrokarbon Minyak Bumi Skala Laboratorium. Jurnal IImu Dasar, 8(1):13-23.

Nursyirwani \& Amolle, K.C. 2007. Isolasi dan Karakterisasi Bakteri Hidrokarbonoklastik dari Perairan Dumai dengan Sekuen 16S rDNA. IImu Kelautan, 12(1):12-17. DOI: 10.14710/ ik.ijms.12.1.12-17.

Prasad, G. \& Anuprakash, M.V.V.S.. 2016. Pollution Due to Oil Spills in Marine Environment And Control Measures. IOSR Journal of Environmental Science, Toxicology, and Food Technology, 10 (1):01-08. DOI: 10.9790/2402-1009010108.

Ristiati, N.P., Sanusi, M. \& Putra, I.M.G. 2016. Uji Kemampuan Degradasi Minyak Solar oleh Konsorsium Bakteri Hasil Preservasi dengan Kombinasi Metode Liofilisasi dan Metode Gliserol. Dalam: Prosiding Seminar Nasional MIPA 2016. 258-267.

Salmin. 2005. Oksigen Terlarut (DO) dan Kebutuhan Oksigen Biologi (BOD) sebagai Salah Satu Indikator untuk Menentukan Kualitas Perairan. Oseana, 30(3):21-26.

Sharpley, J.M. 1966. Elementary Petroleum Microbiology. Texas. Gulf Publishing Company. DOI: 
10.1002/jobm.19670070421.

Susanti, I., Kusumaningtyas, R.W. \& Illaningtyas, F. 2007. Uji Sifat Probiotik Asam Laktat sebagai Kandidat Bahan Pangan Fungsional. Jurnal Teknologi Industri Pangan, 18(2):89-95.

Suyasa, I.W.B. 2006. Isolasi Bakteri Pendegradasi Minyak/Lemak dari Beberapa Sedimen Perairan Tercemar dan Bak Penampungan Limbah. Bumi Lestari Journal of Environment, 7(1):01-06.

Umroh. 2011. Bioremediasi Pencemaran Minyak di Sedimen Pantai Balongan, Indramayu dengan Menggunakan Bakteri Alcanivorax sp. TE-9 Skala Laboratorium. Akuatik Jurnal Sumberdaya Perairan, 5 (2):23-31. 